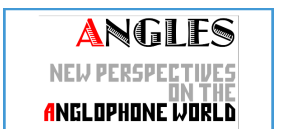

ANELOPHONE WORLD

\section{Angles}

New Perspectives on the Anglophone World

13 | 2021

The Torn Object

\title{
Britain's post Brexit trade deals: Taking back control or a threat to sovereignty?
}

\section{Louise Dalingwater}

\section{(2) OpenEdition \\ 1 Journals}

\section{Electronic version}

URL: https://journals.openedition.org/angles/4707

DOI: $10.4000 /$ angles.4707

ISSN: 2274-2042

\section{Publisher}

Société des Anglicistes de l'Enseignement Supérieur

Printed version

Date of publication: 15 December 2021

\section{Electronic reference}

Louise Dalingwater, "Britain's post Brexit trade deals: Taking back control or a threat to sovereignty?", Angles [Online], 13 | 2021, Online since 15 December 2021, connection on 29 December 2021. URL: http://journals.openedition.org/angles/4707 ; DOI: https://doi.org/10.4000/angles.4707

This text was automatically generated on 29 December 2021.

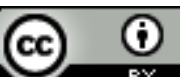

Angles est mise à disposition selon les termes de la Licence Creative Commons Attribution 4.0 International. 


\title{
Britain's post Brexit trade deals: Taking back control or a threat to sovereignty?
}

\author{
Louise Dalingwater
}

\section{Introduction}

1 Brexit has been lauded as an opportunity to be free from the overbearing rules, regulations and enforced mechanisms of the European Union, and more specifically to 'take back control'. Following the UK's exit from the European Union at the beginning of February 2020, in a speech given in Greenwich, Prime Minister Boris Johnson announced: "this is the newly forged United Kingdom on the slipway," and that Brexit had enabled Britain to solve a "long-running question of sovereign authority". Moreover, he claimed it would give Britain more weight in the world: "We have the opportunity, we have the newly recaptured powers, we know where we want to go, and that is out into the world" (Johnson 2020).

2 Yet, as Gammage and Syrpis (2020) underline, defining what 'take back control' or notions of sovereignty imply is not clear. Adhesion to the EU may be viewed as pooling sovereignty, so that control remains not only in the domestic sphere but also over international markets in which sovereign states trade. The debates surrounding Brexit have clearly revealed another vision of sovereignty, that of protecting a country's interests above all other considerations. Brexiters contend that being part of the EU diminishes Britain's absolute power and calls into question its sovereign power because it cedes a part to the supranational level.

Since the UK withdrew from the EU, it has signed a significant number of agreements and trade deals. ${ }^{1}$ However, new generation Free Trade Agreements (FTAs), which are necessary if Britain is to regain international markets after its departure from the EU, may well call into question Britain's sovereign powers. FTAs are no longer just about free trade. Indeed, a whole number of behind-the-border issues related to the political 
and social spheres are now included in comprehensive deals. The wide scope of comprehensive trade deals today has led some commentators to question whether free trade deals are really free at all (Velut 2017). The 'take back control' rhetoric thus lacks a depth of understanding and knowledge of the actual impact of FTAs on sovereign states.

This conceptual paper thus seeks to discuss, through extensive analysis of FTAs signed by the UK and/or in process, how the new landscape of comprehensive and progressive trade agreements may call into question notions of sovereignty. It starts with a brief review of the literature on sovereignty before looking more closely at how Britain's current trade approach to FTAs may undermine sovereignty. It will discuss how provisions in FTAs such as public procurement, competition, Investor State Dispute Settlement (ISDS) and Trade-Related Aspects of Intellectual Property Rights (TRIPS)Plus clauses may well impede attempts at regaining full sovereign control. The limitations imposed by FTAs will be examined through the lens of three significant trade deals: the EU-UK Trade and Co-operation Agreement signed on 24 December 2020 and ratified on 28 April 2021; the US-UK trade deal which is currently being negotiated; and the UK's potential adhesion to the Comprehensive and Progressive Agreement for Trans-Pacific Partnership (CPTPP). The article draws on extensive secondary material: government documents, official speeches, and research papers, as well as global governance and state theory literature.

\section{The Concept of Sovereignty and the Brexit Debate}

5 First of all, it is important to underline the complex nature of notions of sovereignty which is a difficult term to define. Earlier studies of sovereignty point to the emergence of sovereign rule following the peace treaties in 1648, known collectively as the Peace of Westphalia, which set forth the inviolability of borders and non-interference in the domestic affairs of sovereign states. Brown considers sovereignty to describe both legal and political status (Brown 2001: 128). It refers to the triple capacity of a state with supremacy over domestic affairs, the right to govern over its people and freedom from outside interference (Wang 2004: 473). The political meaning of sovereignty is the control and administration of a government or governmental entity (Smith 2016).

While the traditional sense of sovereignty implied the ability of a state to make decisions on domestic policy within its borders, free from external interference, globalisation has diminished the boundaries of governments' abilities to control such decisions. This is because co-operation among trading partners is essential to support international trade and investment. Free trading areas and free trade agreements have thus become central to trade policy-making. Yet, whether it be the EU's single market or trade agreements, there is not necessarily a loss, but a pooling of sovereignty because control is inevitably extended across borders and the boundaries of the state. The process is called pooling of sovereignty because national governments' sovereignty is not replaced by a central sovereign power. The state-centric approach argues that European integration is not a challenge for the autonomy of members states. Rather, it preserves and even reinforces state sovereignty. The supranational actors simply help member states come to agreements. As Robin Niblett argues, it is indeed questionable whether the UK really ceded sovereignty by joining the EU. The British government still had the power to determine most policies for British voters relating to health, 
education, pensions, welfare, monetary policy, defence and border security. The UK controlled more than $98 \%$ of its public expenditure (Niblett 2015). The European Communities Act 1972 allowed for a degree of protection of Parliament. Parliamentary sovereignty co-existing with EU membership was also upheld by section 19 of the European Union Act of 2011. So, as Juliette Ringeisen-Briardeaud (2017) posits, the argument that European law overrides UK law is only true insofar as Parliament accepts it. Furthermore, EU law which is exercised in the UK is a result of the exercise of parliamentary sovereignty and should in no way be considered a threat to it (Elliott 2016). Besides, in the EU, the UK could help decide on responses to challenges which go beyond borders such as environmental sustainability, internet governance, and terrorism. According to Martin Wolf (2016), arguments in favour of taking back sovereign control seem to confuse sovereignty and effective power or the ability to control forces which may affect a country's security and/or prosperity. At the expense of trying to maintain maximum sovereignty, the UK has thus abandoned formal structures of economic co-operation during a period when globalisation has underlined the limits of sovereign governments' ability to ensure full prosperity to the people (Niblett 2015).

7 Yet the several roles that the UK has promoted post-Brexit are in sharp opposition to this: the global trading state, great power, leader of the Commonwealth, ally of the US, have been ways of promoting a post-Brexit sovereign status. It was claimed that these roles would allow for greater international autonomy, "free from the shackles of the EU" (Daddow 2019). Before Johnson, Theresa May also supported a vision of Global Britain and the government underlined its global reach and world class capability, economic strength and soft power.

8 The Global Britain mantra can, in part, be related to the historical search for a new identity. Part of this approach has involved the promotion of the "Anglosphere" or the idea of uniting the nations of the English-speaking world. It was popularised in the late $19^{\text {th }}$ century when, like today, Britain was searching to boost its influence once again in the world, notably through a closer alliance with English-speaking trading partners, notably the United States, but also the former dominions of the British Empire: Canada, Australia, New Zealand and South Africa. Winston Churchill revived this idea in his four-volume publication, A History of the English-Speaking Peoples, (Churchill 1956) in which he celebrates the contributions of English-speaking statesmen for the construction of the rule of law, democracy, and free enterprise. In 1999, former Prime Minister Margaret Thatcher also celebrated the achievements of the Anglosphere during a speech to the English-speaking Union. But, of course, the greatest show of Anglosphere pride (or Empire 2.0. as some critics have dubbed it) in recent times was in the period leading up to the referendum on Britain's exit from the European Union (Kenny \& Pearce 2018). David Davis, Secretary of State for Exiting the European Union under Theresa May's government, announced in the run up to the referendum in 2016: "This is an opportunity to renew our strong relationships with Commonwealth and Anglosphere countries" (Davis 2016). After the referendum, in a speech during a trip to Australia in July 2017, Boris Johnson praised Churchill and his ability to depict the "special genius of the English-speaking peoples". Beyond the Anglosphere, the idea that Britain could also make the most of trading with emerging nations, such as China and India, was also very much part of the Global Britain mantra, although the Anglosphere rhetoric tended to draw the most attention. 
9 However, Verovšek (2020) argues that the populist 'take back control' conception of sovereignty successfully deployed by the Leave campaign (those who supported leaving the EU) is outdated because it claims that the state is still able to make all decisions within its borders. It would therefore seem that the notion of "sovereignty" for Brexiters is completely misunderstood, or, at best, a rhetorical tool influenced by "imperial nostalgia". The rhetoric is also based on a misunderstanding of what the European Union actually is, or how it works as an institution. The fact that the question "What is the EU" was the second most popular question posed by UK residents on Google Trends just after the referendum, suggests that there was a misunderstanding of what the EU was as an institution, and ultimately how it impacted on national sovereignty.

10 Remainers (those who supported staying in the EU) had a different view on sovereignty. They considered country-based notions of sovereignty to be outdated, and that the EU's pooled sovereignty was a more appropriate form of power and authority. Cameron argued that sovereignty does not necessarily mean influence and that the Leave campaign's form of sovereignty was promoting an illusion of power (Parker 2016). Through EU membership, the UK had more influence in the world, and pooled sovereignty did not restrict national power. Leading up to the referendum campaign in 2016, foreign commentators confirmed this view with New Zealand's Prime Minister stating that Britain had a stronger position in Europe (Jones 2016; Beasley et al. 2021). German Finance Minister Wolfgang Schäuble went as far as to say that leaving the EU would weaken the UK's power and sovereignty in an era of globalisation (Hoffmann \& Reiermann 2016; Beasley et al. 2021). US President Barack Obama underlined that EU membership magnified the power of the UK and it would be reduced outside Europe. All such contentions supported the idea that individual state sovereignty was limited in an interdependent world. Indeed, a EU Brexit official was quoted saying that "there is no such thing as a sovereign country anymore [...] it is an illusion the Brits are all chasing" (Barker 2018).

11 Yet Brexit also sparked a debate on where sovereign power lay: with the people, parliament, devolved political authorities or the central UK government. The May government argued it lay with government and their ability to trigger Article 50 of the Treaty of Lisbon to set the EU exit in motion. The Supreme Court ruled parliament must be consulted and executive power limited. The vote by parliament to trigger Article 50 was made by MPs on behalf of their constituents, i.e. in deference to popular sovereignty. The UK's devolved political system also raised questions of sovereignty. While the Court ruled in favour of central government, it did not rule on the status of the devolved nations in the withdrawal from EU laws (The National 2018). Northern Ireland and the "backstop" (mean to prevent a 'hard border' between Northern Ireland and the Republic of Ireland) was yet another reason to raise questions of sovereignty as it was argued that it represented a threat to the UK's integral sovereignty (Hayward \& Vaughan 2019).

12 Elliott (2020) argues that the whole debate on taking back control has thus been based on the underlying premise that sovereignty can be 'maintained', 'preserved' or 'recovered'. It is thus presented as a binary concept: something that a State either possesses or does not possess, or something that can be given away or recovered. This underlines how sovereignty has been misconceived because it is not a binary concept. 
In fact, accepting that there are 'limitations' on sovereignty by entering into legally binding international arrangements is

a means of exercising sovereignty, whereby the legal resources of the State are harnessed in the service of objectives that are judged, in political, economic, diplomatic or other terms, to be worthwhile - and, critically, to warrant the reduced freedom of action thereby entailed (Elliott 2020)

Since departure from the European Union, the debate is now around to what extent Britain's new trading model enables it to regain full sovereignty.

\section{How Free are Free Trade Agreements? Gaining back control or a restriction on sovereignty?}

\section{The ideological arguments on sovereignty related to Free Trade Agreements (FTAs)}

In a report written by the House of Lords European Union select committee six months after the referendum, it was argued that there is necessarily an inherent trade-off between liberalising trade and exercising sovereignty. It posited that this was the case when the UK joined the EEC (European Economic Community) and traded preferential access for sovereignty, and that this would also apply in light of the UK seeking comprehensive trade relationships with the EU and other countries post-Brexit. Sovereignty is necessarily restricted because trade agreements require harmonisation of rules for products to remove tariffs. As an EU Member State, the UK was subject to the Court of Justice of the European Union (CJEU). Outside the EU, it is subject to rules which are binding under international law whether that be on WTO terms or other. The report thus concludes that "the notion that a country can have complete regulatory sovereignty while engaging in comprehensive free trade with partners is based on a misunderstanding of the nature of free trade". Indeed, modern FTAs have extensive regulatory harmonisation which are necessary to eliminate namely non-tariff barriers. The report concludes that the deeper the agreements, the greater the loss of sovereignty will be.

Such a conclusion is in sharp contrast to Theresa May, Boris Johnson, and trade secretary Liz Truss' statements which imply free trade agreements are 'free' and will allow Britain to dictate the rules of the game.

Theresa May, in her Lancaster House speech of 17 January 2017, underlined the importance of parliamentary sovereignty, which she suggested was undermined by being part of the EU:

Parliamentary Sovereignty is the basis of our unwritten constitutional settlement. We have only a recent history of devolved governance - though it has rapidly embedded itself - and we have little history of coalition government. The public expect to be able to hold their governments to account very directly, and as a result supranational institutions as strong as those created by the European Union sit very uneasily in relation to our political history and way of life. (May 2017)

Leaving the EU is thus described as a way of restoring that sovereignty:

Our vote to leave the European Union was no rejection of the values we share. The decision to leave the EU represents no desire to become more distant to you, our friends and neighbours. It was no attempt to do harm to the EU itself or to any of its remaining member states. We do not want to turn the clock back to the days when 
Europe was less peaceful, less secure and less able to trade freely. It was a vote to restore, as we see it, our parliamentary democracy, national self-determination, and to become even more global and internationalist in action and in spirit. (May 2017)

Boris Johnson does not specify what kind of sovereignty he is wishing to recapture. But on 31 January 2020, in his address to the nation just hours before leaving the European Union, he claimed it would enable the country to make its own laws and rules:

This is the moment when the dawn breaks and the curtain goes up on a new act in our great national drama. And yes it is partly about using these new powers - this recaptured sovereignty - to deliver the changes people voted for. Whether that is by controlling immigration or creating freeports or liberating our fishing industry or doing free trade deals. Or simply making our laws and rules for the benefit of the people of this country (Johnson 2020)

Trade secretary Liz Truss also argued:

I think we're in a very strong position to fight against protectionism with our allies, to lead by example through this network of free trade agreements [...] What we will do is we will be able to challenge those who don't play by the rules and we'll be able to force those nations to up their game (Truss 2020)

Boris Johnson continues to insist that the UK has regained control and sovereignty thanks to its decision to leave the EU. In a speech to the Centre for Policy Studies on 22 November 2021, he argued:

This country has resumed its role as the great global agitator and campaigner for free trade. We have done free trade deals with 70 countries around the world plus the EU including New Zealand who I'm glad to see represented here. (Johnson 2021)

21 In all his speeches since the UK's departure from the EU, and despite clear trade disruption, he is very upbeat about Britain's potential gains from FTAs. He claims that the difficulties can be quickly resolved, that trade deals have already led to significant gains for the UK, and that the UK is deciding on the rules of the game:

We have persuaded the Japanese to eat more of our Stilton, how much of our Stilton I don't know. They have the option of eating our Stilton. We have persuaded the Americans to eat not just British beef, but to get rid of their punitive tariffs on Scotch whisky. And we have persuaded Australians to dispense with the requirement that young Britons who want to go and live and work in Australia must spend six months working on a farm. (Johnson 2021)

In the same speech, after a ridiculous reference to Peppa Pig, he claims that the UK will be leading the world and that trade deals give the UK significantly more power to protect products and innovations. His simplified reference to free trade and the issues surrounding IP are far removed from the complex issues surrounding FTAs:

But what amazed me most of all was the discovery that this hairdryer shaped pig has already got two theme parks in her honour in China and two I think in America and she is currently exported, her shows and her merchandise, to 180 countries around the world in a multi-billion pound franchise. Isn't that an astonishing thing?

And I want to leave you with this closing thought. Think how much more we could do when we revive the slightly moribund world trading system and protect our intellectual property with deals, with the CPTPP and so many others. And do more to send fantastic products like Peppa Pig around the world. If we can sell this Picasso-oid pig to Chinese children there is no limit to our creative abilities.

Peppa's influence, cultural influence - she's got a younger brother called George by the way - is so pervasive that kids in America now say 'tomato' instead of 'tomato' and 'mummy' rather than 'mom'. And there you go - that is believed to be a direct 
result of Peppa Pig and that is the effect of the free trade in which Margaret

Thatcher believed. (Johnson 2021)

This media file cannot be displayed. Please refer to the online document http:// journals.openedition.org/angles/4707

24 rhetoric they use in public speeches, they certainly do not seem to understand the full weight of FTAs and their impact on sovereign states.

\section{Technical barriers to full sovereignty in FTAs}

As Velut (2017) argues, free trade deals are actually not free at all. While the aim is to reduce barriers to trade, they also contain a number of provisions which dictate the restrictions on trade, mainly in the form of non-tariff barriers (NTB), which signatory countries wish to maintain. ${ }^{2}$

In analysing how FTAs may restrict sovereign powers, it is important to consider two concepts relating to corporate economic autonomy and nation-state economic autonomy. While there is general acceptance of the importance of free market enterprise, remaining competitive, and ensuring maximum productivity and growth in an economy, the extent of corporate economic autonomy is debatable. The US, for example, is considered to have given a considerable degree of corporate economic autonomy to companies and organisations. The same is true in the UK, where neoliberalism fused with public choice theory has reduced interventionism and further supported corporate autonomy. International trade has thus been dictated along those grounds, and the multilateral trading regime rewritten, so that interventionist domestic policies are seen as trade distorting (Howse 2002; Molyneux 2001). However, a paradox emerges with the protectionist stance of the US and the significant state support given to protect domestic industries such as steel. The nationalistic debate in the UK is also in sharp contradiction to the significant degree of multinational corporate economic autonomy in this country.

Funke and Zhong (2020) argue that hyper-globalisation and democratic politics have made it difficult to achieve national sovereignty, because globalisation constrains domestic economic policymaking and results in restricting the domestic policy space. Globalisation is seen as a threat to national sovereignty due to global financial flows, multinational co-operation power, the internet, etc. (Grinin 2012). Multinationals have a major impact and they are important sources of income. If a state fails to ensure conditions are right for multinationals, it loses out on global competitiveness. Supranationality is thus seen as a threat to national sovereignty because it implies a situation whereby an international authority can impose its will on sovereign and independent states (Zahiti 2000).

Free trade agreements can strengthen corporate power. Such agreements dictate the rules of trade across the world and particularly in the $21^{\text {st }}$ century. Trade deals, whether they be cross-regional agreements such as CETA (Comprehensive Economic and Trade Agreement between Canada and the EU) and CPTPP, or bilateral deals which have been signed or are in progress between the UK and partner countries, attempt to eliminate, reduce or prevent behind-the-border non-tariff barriers (NTBs). As Finbow 
(2016) underlines, the WTO process has led to the signature of a significant number of regional and bilateral agreements, raising new issues which have been said to threaten national sovereignty (or a government's right to govern on issues of national concern), particularly in areas relating to investment, intellectual property, public services and regulations. Finbow (2016) argues that transnational corporate and institutional elites which push for economic agreements narrow the scope of democratic governance; they not only constrain but also empower states through transnational agreements. The latter force liberal democracies to make changes to programmes and regulations in both the economic and social fields which protect investor rights, but restrain the rights of democratic governments, especially in the areas of intellectual property rights and investor state arbitration and disputes settlement systems. Gathii (2011) argues that bilateral and regional trade agreements are the main ways to increase investor protection, commodify social services and guarantee rights to investors, privatise public services, and reduce sovereign control. Cerny, Menz and Soederberg (2005: 19) have pointed to a powerful alliance of transnational institutions, corporations, private lobbies, think tanks and epistemic communities who work towards increasing investor rights, intellectual property protections, and deregulation at the expense of a government's democratic accountability. States which are bound to these transnational agreements see their actions constrained.

There is nevertheless a debate on the extent to which FTAs threaten state sovereignty and democratic governance. Some, like Colin Crouch (2000), point to a post-democratic era with the advent of increased global connectivity. Others, such as Caroll and Sapinski (2010), lament the loss of power to global corporate elites. Held (2004: ch. 5) points to an "unbundling of sovereignty" or the "end of exclusive state control of territory and population" and the emergence of a "global governing complex" with a "plurality of actors and diverse levels of coordination". He describes how networks are both formal and informal, involving diverse business actors who are seeking to establish transnational regulatory mechanisms on their own terms, even though to a certain degree they can be countered by NGOs and transnational advocacy networks. There are thus specific provisions in trade agreements which increase the power of investors but at the same time limit actions of national governments.

\section{Investor protection and limitations to national government intervention}

Investment protection is seen as a particular threat to national sovereignty because it constitutes external influence on governmental decision-making. Karas defines national sovereignty as "the ability of a legitimate government to regulate investment environment within its borders" (2019: 51), drawing on Krasner's Westphalian conception of sovereignty. In this conceptualisation, full sovereignty implies a distinct lack of other authority over the state and domestic authority.

Finbow (2016) demonstrates that one of the main achievements of transnational actors and networks has been the creation of a regime for investment. The Investor State Dispute Settlement (ISDS) allows potential investors to challenge and even sue states if they have real or potential profit losses. The cases are judged in tribunals. Arguments in favour of ISDS provisions are that they protect investors and provide clear investment rules. The United Nations Conference on Trade and Development (UNCTAD) 
states that: "IIAs [International Investment Agreements] may offer an avenue for the resolution of investor state disputes that allow significant disagreements to be overcome and the investment relationship to survive." Remedy can also ensure business as usual (UNCTAD 2003: 8 qtd in Finbow 2016: 68). However, critics see ISDS mechanisms as threats to democracy and public policy, which can call into question environmental protection and regulations. Trade unions and NGOs criticise the independence and impartiality of arbitrators. The concern is that ISDS provisions in trade agreements may allow investors to overturn domestic courts, laws or regulations which are in place to protect public health and wellbeing. Costly settlements and successful outcomes for investors restrict state decision-making and rights to rule. Examples are notably given in the case of Canada and the US under the NAFTA agreement, whereby Canadian provinces, notably Quebec and New Brunswick, were faced with challenges when they attempted to limit fracking. Other contentious ISDS cases are included in the table below:

\begin{tabular}{|c|c|}
\hline \multirow{2}{*}{ Health Care } & Eli Lilly vs Canada (drug prices) \\
\hline & Phillip Morris vs Uruguay (tobacco) \\
\hline \multirow{5}{*}{$\begin{array}{l}\text { Environmental } \\
\text { Protection }\end{array}$} & Chevron vs Ecuador (Amazon protection) \\
\hline & Vattenfall vs Germany (nuclear energy ban) \\
\hline & Renco vs Peru (mining permits and wastes) \\
\hline & Lone Pine Resources vs Canada (fracking ban) \\
\hline & Windstream Energy vs Canada (green energy) \\
\hline \multirow{3}{*}{ Labour Rights } & Veolia vs Egypt (minimum wage) \\
\hline & Laval vs Sweden (contract labour standards) \\
\hline & Piero Foresti vs South Africa (affirmative action) \\
\hline \multirow{3}{*}{ Financial Institutions } & Abalclat vs Argentine Republic (debt relief) \\
\hline & Saluka vs Czech Republic (too big to fail) \\
\hline & $\begin{array}{l}\text { Utilities Vivendi vs. Argentina (water/wastewater } \\
\text { pricing) }\end{array}$ \\
\hline
\end{tabular}

Source: Van Harten, Porterfield \& Gallagher (2015)

While tribunals will defend "reasonable governmental regulation", in a number of cases multinationals have been able to use non-democratically-elected international tribunals to sue states for preventing trade and investment.

More recent comprehensive agreements such as the CETA provide explicit statements on the rights of states to regulate in public interest with the following clause:

the Parties reaffirm their right to regulate within their territories to achieve legitimate policy objectives, such as the protection of public health, safety, the environment, or public morals, social or consumer protection or the promotion and protection of cultural diversity (Article 23.2).

Recent agreements have also featured adjustments to protect government authority to regulate in areas of consumer protection, the environment, health standards, and human rights (de Mestral 2015: 2; Finbow 2016). However, some analysts have suggested that despite these improvements, the arbitration model still constrains sovereignty and democratic governance (Butler 2016). 


\section{Intellectual Property (IP) Protection}

Another major issue is that of rising drug prices due to trade deals which have hiked up Intellectual Property (IP) protectionism. The Trade Related Aspects of Intellectual Property Rights (TRIPS) negotiated at the end of the Uruguay Round of the General Agreement on Tariffs and Trade (GATT) between 1989 and 1990 and administered by the WTO was intended to harmonise Intellectual Property Rights (IPR). The Doha Declaration on the TRIPS Agreement and Public Health aimed to restore the balance and enable developing countries to have access to essential medicines through "flexibilities" which balanced intellectual property protection and public health imperatives. However, the US has sought, through bilateral and regional trade agreements, to reinforce IPR. Many of their bilateral FTAs have included TRIPS-plus standards which demand that the signatory countries agree to tighter IP protection than those of the TRIPS, without the flexibilities. The US argument is that the current TRIPS does not provide sufficient protection for pharmaceuticals and recovery of R\&D costs. TRIPS-plus thus includes provisions which extend patent protection beyond the 20 -year period. The adoption of such provisions results in stronger patent protection and can thus lead to static welfare losses because of monopolistic powers (whereby one or very few suppliers are present in the market enjoying a monopoly and gaining extraordinary profits), which can result in higher prices for consumers and unaffordable drugs. Wide-spread use of patents prevent cheaper generic versions coming onto the market and bringing down the cost of essential medicines. There are thus deep concerns about recent trends to extend patent terms beyond the 20-year TRIPS period.

Given these potential restrictions on the ability for governments to decide on issues of national importance, and more specifically on essential issues such as public health and workers' rights, among others, it is worth considering potential threats from current and future trade deals for the UK, given that all trade deals require parties to change part of their domestic legislation in order to be able to reduce tariffs. This is because such changes will have an impact on tax laws, laws relating to treatment of foreign firms, consumer safety or state dispute resolution.

\section{Post-Brexit Trade Deals}

\section{The EU-UK Trade and Co-operation Agreement (TCA): Trading prosperity for sovereignty?}

On 24 December 2020, the EU and the UK reached a trade deal to define their future trading relationship following a long and contentious series of negotiations during the transition period, the Trade and Co-operation Agreement (TCA). The agreement alleviated all tariffs and quotas on goods traded between the two partners, although this did not alleviate non-tariff barriers and has created logistical, regulatory, and administrative challenges. This agreement has also imposed restrictions notably on animal products which no longer follow EU product standard regulations.

On signing the TCA agreement, UK Prime Minister Boris Johnson boasted:

we will take back control of our trade policy and leave the EU customs union and single market. We will take back control of our waters, with this treaty affirming 
British sovereignty over our vast marine wealth. We will take back control of our money by ending vast payments to the EU. We will take back control of our borders and will introduce our new points-based immigration system at the start of next year. Most importantly, the agreement provides for the UK to take back control of our laws, affording no role for EU law and no jurisdiction for the European Court of Justice. The only laws we will have to obey are the ones made by the Parliament we elect (Johnson 2021)

Johnson and Brexiters may well argue that the TCA reaffirms sovereignty because it does not give full powers to the EU Court of Justice to resolve disputes. However, the UK is still bound to some extent to the rules and regulations of the EU. If it diverges from EU standards not only in the economic sphere but in areas such as workers' rights or environmental protection, tariffs may be reinstated. Moreover, both parties have agreed to a dispute settlement system which includes an independent arbitration body if two corporate entities cannot resolve disputes. The UK and the EU have nominated an equal number of independent arbitrators. Non-compliance of arbitration can lead to the suspension of treaty obligations.

As it is no longer a member of the EU, the UK can no longer be part of EU-led negotiations with third parties which might have previously avoided penalties, and in this case, the imposition of tariffs. As Elliott (2020) underlines, the UK has become "a rule-taker" rather than a "rule maker". Kaplan (2018) argues that even if we accept the misconceived idea that the UK has regained sovereign power, it has inevitably traded sovereignty for prosperity, because the new agreement does not provide sufficient protection for the City of London or the car industry. Most estimations predict the long-term losses to output to be high. The same kind of trade-offs are evident if we consider the potential US-UK trade deal.

\section{The US-UK deal : A threat to public health governance?}

41 As the Biden administration does not see the UK-US deal as a priority, it is likely to be a long, drawn-out affair. The negotiations for a UK-US trade deal were launched on 5 March 2020. A UK-US FTA is seen as an important opportunity for the UK to increase trade with its most important trading party. A government document predicted $£ 15.3$ billion worth of gains in the long run, and an increase in UK workers' wages over 15 years, and a reduction in prices for consumer goods (Department for International Trade 2020: 5); it also estimated that a digital trade chapter should also enable the UK to maximise digital trade with the US.

Before the negotiations began, each party published its objectives. The US stated in a publication, dated February 2019, that it was particularly interested in gaining access to the UK food market, alleviating barriers which have thus far reduced US access to agricultural markets (Office of the US Trade Representative 2019). It has notably requested the reduction in non-tariff barriers, such as standards for goods which constitute discrimination against US agricultural goods. However, changing food standards to allow the US to access its agricultural markets could result in the resurrection of trade barriers with the EU if the UK deviates too far from EU standards on food safety, which is why the UK document which sets forth its negotiating position underlines that food standards will be upheld and no significant changes to food regulation will be made. It also states its reservations on the liberalisation of tariffs in agriculture (Department for International Trade 2020). 

was concern about protecting the NHS and other threats to public health from bilateral trade agreements. Protection for the UK was called for and it was requested that provisions on government procurement be carefully drafted. In addition, respondents also mentioned the ISDS mechanism. Global Justice Now and War on Want criticised the ISDS and the fear of the creation of "secret courts" with legal power extending outside the UK legal framework. They called for a special grievance mechanism to ensure that individuals, groups or communities could be defended against corporate investors. The statement about establishing a dispute settlement merely states that appropriate mechanisms which promote compliance will be set up. question of the pharmaceuticals agreement, the UK's positioning paper does underline that its commitment to the Doha Declaration on Public Health and the TRIPS Agreement, including the agreed flexibilities to support access to medicines. At the same time, it proposes to uphold competition clauses. With regard to government procurement, it proposes to go beyond the level set by the WTO Government Procurement Agreement (GPA) while providing appropriate regard to public interests including the need to maintain protection for key public services such as the NHS. However, no mention is made of the intention to exclude TRIPS-plus clauses or how to mitigate the potential impact of such clauses on prices negotiated in the NHS. In the overall objectives stated in the Department of Trade March 2020 document, the government states that it intends to exclude price negotiations for drugs: "The price the NHS pays for drugs will not be on the table." (Department of Trade 2020). But this statement remains vague. The government will still need to clarify how excluding price of drugs from negotiations, as mentioned in the UK Department of Trade document, could be achieved if TRIPS-plus clauses are indeed included in the free trade agreement. The key challenge will therefore be to stand ground against US pressure to change the way it regulates pharmaceuticals in trade deals. The proposed UK-US FTA thus underlines a host of possible curtailments on the ability of the British government to act in the national interest, mainly in areas of public health and wellbeing, which raises significant concern.

\section{Adhesion to the CPTPP. Another example of containment of sovereign powers?}

45 The UK is also looking to be a part of a mega-cross regional agreement: the Comprehensive and Progressive Agreement for Trans-Pacific Partnership (CPTPP). As International Trade Secretary, Liz Truss underlined "of all the opportunities I've seen I think CPTTP is one of the greatest [...] Membership of CPTTP would hitch the UK to the fast-growth Pacific region." (Truss 2020) She claims that there would only be advantages and no obligations: "There is no ECJ and there is no harmonisation of domestic regulation and there is no seizing of our sovereign power." (Truss, 2020) She underlines that the British government would be working to secure accession. On 1 February 2021, Truss announced that the UK had notified the CPTPP of its intention to join.

The CPTPP was signed by 11 countries of the Pacific following the withdrawal of the US from the agreements: Australia, Brunei, Canada, Chile, Japan, Malaysia, Mexico, New 
Zealand, Peru, Singapore, and Vietnam. This trading area represents $13.5 \%$ of world GDP (Institute for Government 2020). Entering the CPTPP is part of the "Global Britain" post-Brexit strategy. The initial process for Britain has been to first develop bilateral discussions and agreements with the 11 member countries. Yet some have questioned the benefits of joining the CPTPP after the bilateral agreements have been signed, especially given that the UK's industrial chain is not particularly linked to the AsiaPacific region. However, the Department of Trade strategy in place since June 2002 has been to shore up presence in the region with a support package to SMEs (Small and Medium-sized Enterprises) wishing to access dynamic Asian markets. However, studying the potential of increasing trade through adhesion to the CPTTP is limited, given the importance of services in the UK economy and the importance of gravity (i.e. closeness to trading partners) for UK services: the further the countries are away from the UK, the greater the difficulties to trade. It is estimated that a $10 \%$ increase in distance reduces trading capacity by $6 \%$ (Van Marel 2021).

In relation to the curtailment of the UK's sovereign powers, it is worth noting that the UK would be requesting accession to the pre-existing partnership, with limited negotiating powers to change the agreement, and it would have to accept the conditions (a 'rule taker' rather than a 'rule maker'). Another issue is that since the main provisions of the CPTTP were established under the previous framework of the CPTTP, which was the TPP and to which the US was party, the standards and regulations are based on a US-system of procedures which are different from the EU's. So the UK would need to adhere or find a balance for different regulatory regimes. It would also involve all the aforementioned threats relating to investor state dispute mechanisms (ISDS) and reinforced IP protection given that it is based on US-style agreements.

Bates (2019) claims that the CPTTP achieves a balance between investment protection and regulatory discretion even though it follows the US-style BIT (Bilateral investment treaty) with protection for investors. It does include procedural safeguards promoting more transparency (article 9.24) with the obligation to make certain documents available to the public. However, some observers argue this may just be a way of legitimising a flawed system. It calls upon states to take a proactive approach in using its interpretive power. It is also noted that the 11 nations must come to a consensus on interpretation and only then may they limit investors' rights.

49 Another issue for the UK would be complying to the rules on agricultural trade. Australia and New Zealand, two big agri-food exporters, have insisted on Britain opening its market to accepting a wider range of products on accession to the CPTTP. However, this again creates the issue of divergence from EU rules and could compromise the advantages of the EU-UK trade agreement. Geoff Raby, an Australian ambassador to the WTO, has argued that despite the request for the UK to join the CPTPP, this would only seem feasible if it agreed to scrap all EU agricultural rules, resulting in severe limitation of British farmers' access to EU markets (De Jonquières 2018).

\section{Conclusion}

The changing nature of world trade means that the UK's notion of sovereignty, promoted by the current and previous Prime Minister, members of government and 
Brexiters, is as misconceived as it is outdated. The interconnectedness of economies means that retaining sovereignty whilst promoting free trade and supporting multinational enterprise is nigh impossible. FTAs have a number of behind-the-border issues which make it impossible to maintain full sovereign power. Thus the reservations made by the House of Lords EU select committee in 2016 following the referendum have clearly proved to be correct. The UK has traded one kind of constraint on sovereignty for another.

\section{BIBLIOGRAPHY}

Barker Alex. “Brexiters Fear ‘Biggest Loss of Sovereignty' Since 1973.” Financial Times, 10 July 2018. https://www.ft.com/content/14ab9916-8396-11e8-a29d-73e3d454535d

Beasley, Ryan, K., Juliet Kaarbo, Kai Oppermann, Role Theory, Foreign Policy, and the Social Construction of Sovereignty: Brexit Stage Right, Global Studies Quarterly 1(1), March 2021: 1-14. DOI: 10.1093/isagsq/ksab001

Brown, Chris. Understanding International Relations. $2^{\text {nd }}$ Edition. New York: Palgrave, 2001.

Butler, Nicolette. “The EU investment court proposal in TTIP: ISDS 2.0." Policy Briefing.

Manchester: University of Manchester, 2016. http://documents.manchester.ac.uk/display.aspx? DocID $=28671$

Carone, Giuseppe, Christoph Schwierz, and Ana Xavie. "Cost-containment policies in public pharmaceutical spending in the EU." Economic Papers, 461. Brussels: European Commission, 2012. DOI: doi: $10.2765 / 27111$

Carroll, William, K. and Jean Philippe Sapinski. "The global corporate elite and the transnational policy-planning network, 1996-2006. A structural analysis." International Sociology, 25(4), 2010: 501-538. DOI: 10.1177/0268580909351326

Cerny, Phillip, Georg Menz, and Suzanne Soederberg. "Different roads to globalization: Neoliberalism, the competition state, and politics in a more open world." In Internalizing Globalization. Eds. Phillip Cerny, Georg Menz and Suzanne Soederberg. New York: Palgrave Macmillan, 2005. 1-30.

Churchill, Winston, S. A History of the English-Speaking Peoples. Volume I, The Birth of Britain. New York: Dodd, Mead and Company, 1956.

Crouch, Colin. Coping with post-democracy. London: Fabian Society, 2000.

Daddow, Oliver. “Global Britain ${ }^{\mathrm{TM}}$ : The Discursive Construction of Britain's Post-Brexit World Role." Global Affairs 5(1) 2019: 5-22.

Davis, David. "Britain would be better off outside the EU - and here's why," ConservativeHome, 4 February 2016. https://www.conservativehome.com/platform/2016/02/david-davis-britainwould-be-better-off-out-of-the-eu-and-heres-why.html 
De Jonquières, Guy. "Future UK trade deals and the question of sovereignty", UK Trade Forum, 26 September 2018. https://uktradeforum.net/2018/09/26/future-uk-trade-deals-and-the-questionof-sovereignty/

de Mestral, Armand. Investor state arbitration between developed countries. Investor-state Arbitration Series 1. Waterloo: Centre for International Governance Innovation, 2015. https:// www.cigionline.org/sites/default/files/isa_paper_series_no.1.pdf

Department of Health, Association of the British Pharmaceutical Industry. "Pharmaceutical price regulation scheme." London: Department of Health, 2014. https://www.gov.uk/government/ publications/pharmaceutical-price-regulation-scheme-2014

Department for International Trade. “UK-US trade deal.” London: HMSO, 2 March 2020. https:// www.gov.uk/government/collections/the-uks-trade-negotiations-with-the-us

Elliott, Mark. “The UK-EU Brexit Agreements and 'sovereignty': Having one's cake and eating it?" Public Law for Everyone, 31 December 2020. https://publiclawforeveryone.com/2020/12/31/theuk-eu-brexit-agreements-and-sovereignty-having-ones-cake-and-eating-it/

European Commission (DG Trade). "Fact sheet: Investment protection and investor-to-state dispute settlement in EU agreements”, 2013. https://www.italaw.com/sites/default/files/ archive/Investment\%20Protection\%20and\%20Investor-to-

State\%20Dispute\%20Settlement\%20in\%20EU\%20agreements_0.pdf

Faunce, Thomas. "How the US trade deal undermined Australia's PBS." The Conversation, 23 October 2014. https://theconversation.com/how-the-us-trade-deal-undermined-australiaspbs-32573

Finbow, Robert G. "Restructuring the State through Economic and Trade Agreements: The Case of Investment Disputes Resolution." Politics and Governance 4 (3) 2016: 62-76. DOI: https://doi.org/ 10.17645/pag.v4i3.639

Funke, Michael, Doudou Zhong. "The political globalisation trilemma revisited: An empirical assessment across countries and over time.” BOFIT Discussion Papers 19, 2020. DOI: 10.2139/ssrn. 3694779

Gammage, Clair, and Philip Syrpis. "The sovereignty illusion: the freedom to set one's rules has a high price." LSE Blog, 23 December 2020. https://blogs.lse.ac.uk/brexit/2020/12/23/thesovereignty-illusion-freedom-to-set-ones-own-rules-has-a-high-price/

Gathii, James Thuo. "The neoliberal turn in regional trade agreements." Washington Law Review 86(3) 2011: 421-474. https://digitalcommons.law.uw.edu/wlr/vol86/iss3/2

Grinin, Leonid. Globalistics and Globalization Studies, Chapter: State Sovereignty in the Age of Globalization. Will it Survive? Volgograd: Uchitel, 2012: 211-237. http://www.sociostudies.org/ books/files/globalistics_and_globalization_studies/211-237.pdf

Hayward, Katy, and Billy Vaughan. "Is the DUP Completely Out of Step with the Wishes of Northern Ireland?" The UK in a Changing Europe, 28 March 2019. https://ukandeu.ac.uk/is-thedup-completely-out-of-step-with-the-wishes-of-northern-ireland

Held, David. Cosmopolitanism: Ideals and Realities. Cambridge, UK: Polity, 2020.

Hoffmann, Christiane, and Christian Reiermann. "Britain Is a Leading Nation. Interview with Wolfgang Schäuble.” Der Spiegel, 10 June 2016. http://www.spiegel.de/international/europe/ spiegel-interview-with-wolfgang-schaeuble-on-brexit-a-1096999.html 
Howse, Robert. "From Politics to Technocracy and Back Again: The Fate of the Multilateral Trading Regime." 96.1 American Journal of International Law (2002) 94-101. DOI: 10.2307/2686127 Institute for Government. "Comprehensive and Progressive Agreement for Trans-Pacific Partnership (СРTPP)”, 2021. https://www.instituteforgovernment.org.uk/explainers/trade-cptpp Johnson, Boris. "PM address to the nation: 31 January 2020." https://www.gov.uk/government/ speeches/pm-address-to-the-nation-31-january-2020

Johnson, Boris. “PM speech in Greenwich.” Prime Minister's Office, 3 February 2020. https:// www.gov.uk/government/speeches/pm-speech-in-greenwich-3-february-2020

Johnson, Boris. "PM's speech at the Centre for Policy Studies." Prime Minister's Office, 22 November 2021. https://www.gov.uk/government/speeches/pms-speech-at-the-centre-forpolicy-studies-22-november-2021

Jones, Nicholas. "John Key Eager for Britain to Stay in European Union." New Zealand Herald. 1 April 2016. https://www.nzherald.co.nz/business/john-key-eager-for-britain-to-stay-ineuropean-union/NJVVLJKETVDJSC2R532FNSILYE/?c_id=3\&objectid=11615225

Karas, Martin. "Trends in Investment Treaty Making: Finding Balance between National Sovereignty and Investment Protection." Central European Journal of International \& Security Studies 13.3 (2019): 49-63. https://www.proquest.com/docview/2394981594

Kaplan, Yilmaz. “(Re)considering sovereignty in the European integration process.”Asian Journal of German and European Studies. 3(1), 2018. DOI: 10.1186/s40856-017-0023-4

Karas, Martin. "Trends in Investment Treaty Making: Finding Balance between National Sovereignty and Investment Protection." CEJISS - Central European Journal of International \& Security Studies 13(3) 2019: 49-63. DOI: 10.51870/CEJISS.A130304

Kaushal, Asha. "Revisiting history: How the past matters for the present backlash against the foreign investment regime." Harvard International Law Journal 50(2) 2009: 491-534.

Kenny, Michael, and Nick Pearce. Shadows of Empire: The Anglosphere in British Politics. Cambridge: Polity Press, 2018.

Miller, Scott, and Gregory Hicks. Investor-state dispute settlement: A reality check. (Report of the CSIS Scholl Chair in International Business Centre for Strategic and International Studies). New York: Roman and Littlefield, 2015. http://csis.org/files/publication/ 150116_Miller_InvestorStateDispute_Web.pdf

Molyneux, Candido Garcia. Domestic Structures and International Trade: The Unfair Trade Instruments of the United States and European Union. London: Bloomsbury Publishing, 2001.

Niblett Robin. Britain, Europe and the World. Rethinking the UK's Circles of Influence. London: Chatham House, 2015.

Organisation for Economic Co-operation and Development (OECD). "Health, pharmaceutical market, pharmaceutical sales.” Paris: OECD, 2017. http://stats.oecd.org

Office of the US Trade Representative, "United States-United Kingdom Negotiations”, February 2019. https://ustr.gov/sites/default/files/Summary_of_U.S.-UK_Negotiating_Objectives.pdf Parker, George. "Brexit: Cameron Warns Britain against 'Step into the Dark”' Financial Times, 21 February 2016. https://www.ft.com/content/557c64ca-d87b-11e5-98fd-06d75973fe09 
Ringeisen-Biardeaud, Juliette. “'Let's take back control': Brexit and the Debate on Sovereignty”. In "The Brexit Referendum of 23 June 2016: The Issues at Stake in the Referendum." Ed. Karine Tournier-Sol. Revue française de civilisation britannique 22(2), 2017. DOI: 10.4000/rfcb.1240

Smith, Chris J. Property and Sovereignty - Legal and Cultural Perspectives. London/New York: Routledge, Taylor \& Francis Group, 2016.

The National. "Nicola Sturgeon Demands Scottish Involvement in Crucial Brexit Talks." The National, 6 February 2018. https://www.thenational.scot/news/15923608.nicola-sturgeondemands-scottish-involvement-crucial-brexit-talks/

Truss, Liz. "Speech: Global Britain and the CPTTP." Department for International Trade, 3 July 2020. https://www.gov.uk/government/speeches/global-britain-and-the-cptpp

United Nations Conference on Trade and Development. "Reform of investor-state dispute settlement: In search of a roadmap.” Geneva: UNCTAD, 2 (June) 2013. https://unctad.org/node/ 4304

Van der Marel, Eric. "UK joining the CPTPP: In Search of the Economic Benefits in Services." European Centre for International Political Economy, February 2021. https://ecipe.org/blog/ukjoining-the-cptpp/

Van Harten, Gus, Matthew Porterfield, and Kevin. P. Gallagher. "Investment provisions in trade and investment treaties: The need for reform." Global Economic Governance Initiative Policy Brief, 5 (2015). http://www.bu.edu/pardeeschool/files/2014/12/Investor-State-Disputes-Policy-Brief.pdf Velut, Jean-Baptiste. “Introduction.” In Understanding Mega-Free Trade Agreements: The Political and Economic Governance of New Cross-Regionalism. Eds. Jean-Baptiste Velut, Louise Dalingwater, Vanessa Boullet and Valérie Peyronel. London: Routledge, 2017.

Verovšek, Peter. "Brexit and the misunderstanding of sovereignty." Social Europe, 9 December 2020. https://socialeurope.eu/brexit-and-the-misunderstanding-of-sovereignty

Wang, Guiguo. "The impact of Globalization on State Sovereignty." Chinese Journal of International Law 3/2 2004: 473-483. DOI: 10.1093/oxfordjournals.cjilaw.a000530

Wolf, Martin. "Brexit: sovereignty is not the same as power." Financial Times, 3 May 2016. https:// www.ft.com/content/fece7238-1071-11e6-91da-096d89bd2173

Zahiti, Bounaj E. Drejta Evropiane/ European Law. Prishtinë: Otografia, 2000.

\section{NOTES}

1. For a full list of trade agreements ratified by the UK, consult: https://www.gov.uk/guidance/ uk-trade-agreements-with-non-eu-countries\#trade-agreements-in-effect. Many of the UK's trade agreements are roll-over agreements (such as that with Canada) to ensure that the UK can continue to benefit from similar trading arrangements to those that existed when the UK was a member of the European Union.

2. Non-Tariff Barriers (NTBs) refer to restrictions that result from prohibitions, conditions, or specific market requirements that make importation or exportation of products difficult and/or costly. 


\section{ABSTRACTS}

In a speech given a few days after Britain officially left the European Union, Boris Johnson boasted about the merits of Brexit which, according to him, paved the way for Britain to take back control and lead a full free trade agenda, renewing ties with the Commonwealth and developing links with high-growth emerging economies. Similar rhetoric, which echoes late Victorian historians like Edward Freeman, was used by David Davis, Michael Gove, the Institute of Economic Affairs (IEA) and the Adam Smith Institute to paint a positive image of Britain outside Europe. Yet, as Gammage and Syrpris (2020) underline, defining what taking back control or notions of sovereignty imply is not clear. Adhesion to the EU may be viewed as pooling sovereignty, so that control remains not only in the domestic sphere but also over international markets in which sovereign states trade. However, the debates surrounding Brexit have clearly revealed another conception of sovereignty, that of protecting a country's interests above all other considerations. Brexiters contend that being part of the EU diminishes Britain's absolute power and calls into question its sovereign power because it cedes a part to the supranational level. Brexit has thus been lauded as an opportunity to be free from the intensive infrastructure of the EU, its rules and enforced mechanisms. Yet Free Trade Agreements (FTAs) may also impinge on Britain's sovereign powers. The 'take back control' rhetoric thus lacks a depth of understanding and knowledge of the actual impact of FTAs on sovereign states. This conceptual paper thus seeks to discuss, through extensive analysis of FTAs signed by the UK and/or in process, how the new landscape of comprehensive and progressive trade agreements may call into question notions of sovereignty. It will attempt to show how imperial nostalgia and Britain's ambitions to take back control ignore the reality of FTAs in which public procurement, competition, ISDS and TRIPs-Plus clauses may well undermine attempts at regaining full sovereign control. The article draws on extensive secondary material: government documents, official speeches, and research papers.

Dans un discours prononcé quelques jours après que la Grande-Bretagne a officiellement quitté l'Union européenne, Boris Johnson a vanté les mérites du Brexit qui, selon lui, a ouvert la voie à ce que la Grande-Bretagne reprenne les choses en main et mène un programme de libre-échange global, en renouvelant les liens avec le Commonwealth et en développant des liens avec les économies émergentes en forte croissance. Une rhétorique similaire, qui fait écho à des historiens de la fin de l'ère victorienne comme Edward Freeman, a été exploitée par David Davis, Michael Gove, l'Institute of Economic Affairs (IEA) et le Adam Smith Institute pour donner une image positive de la Grande-Bretagne en dehors de l'Europe. Pourtant, comme le soulignent Gammage et Syrpris (2020), la définition de ce qu'implique le fait de recouvrer sa souveraineté, et la notion de souveraineté, ne sont pas claires. L'adhésion à l'UE peut être considérée comme une mise en commun de la souveraineté, de sorte que le contrôle demeure non seulement dans la sphère intérieure mais aussi sur les marchés internationaux avec lesquels les États souverains entretiennent des relations commerciales. Cependant, les débats autour du Brexit ont clairement révélé une autre conception de la souveraineté, celle de la protection des intérêts d'un pays avant toute autre considération. Les partisans du Brexit soutiennent que l'appartenance à l'UE limitait le pouvoir absolu de la Grande-Bretagne et remettait en question son pouvoir souverain, car elle cédait une partie du pouvoir à une structure supranationale. Le Brexit a donc été salué comme une occasion de se libérer du système de l'UE, de ses règles et de ses mécanismes d'application. Pourtant, les accords de libre-échange (ALE) peuvent également empiéter sur les pouvoirs souverains de la Grande-Bretagne. La rhétorique de la "reprise en main » témoigne donc d'une mécompréhension et d'une mauvaise connaissance de l'impact réel des ALE sur les États 
souverains. Cet article conceptuel vise donc à examiner, par le biais d'une analyse approfondie des ALE signés par le Royaume-Uni et/ou en cours après le Brexit, comment le nouveau paysage des accords commerciaux mondiaux et progressifs peut remettre en question les notions de souveraineté. Il tentera de montrer comment la nostalgie impériale et les ambitions de la Grande-Bretagne de recouvrer sa souveraineté ignorent la réalité des ALE qui contiennent des clauses relatives aux marchés publics, à la concurrence, aux mécanismes de règlement des différends entre investisseurs et États (ISDS), et à l'ADPIC-Plus, qui pourraient bien saper les tentatives de reprise en main de la souveraineté britannique. L'article s'appuie sur de nombreuses sources secondaires: documents officiels, discours gouvernementaux et rapports scientifiques.

\section{INDEX}

Mots-clés: souveraineté, Grande-Bretagne, Brexit, Accords de libre-échange (ALE), Union Européenne, économie, commerce, échanges, mécanisme de règlement des différends entre investisseurs et États (ISDS), Accord sur les aspects des droits de propriété intellectuelle qui touchent au commerce (ADPIC)

Keywords: sovereignty, Brexit, Great-Britain, Free Trade Agreements (FTAs), European Union, economics, trade, commerce, Investor State Dispute Settlement (ISDS), Trade-Related Aspects of Intellectual Property Rights (TRIPS)

\section{AUTHOR}

\section{LOUISE DALINGWATER}

Louise Dalingwater is Professor in British politics at Sorbonne Université, Paris. Her current research focuses on trade in services, health and wellbeing in the United Kingdom. She co-edited the recent publication Understanding Mega Free Trade Agreements: The Political and Economic Governance of New Cross-Regionalism (Routledge, 2017) with Jean-Baptiste Velut, Vanessa Boullet and Valérie Peyronel and the special section The Dynamics of Inclusion and Exclusion in Trade Politics in the journal New Political Economy with Jean-Baptiste Velut and Gabriel Siles-Brügges. She has also written several academic articles and chapters on trade. Contact: louise.dalingwater [at] sorbonne-universite.fr 